\title{
Articles
}

\author{
DARIA DUBOVKa
}

\section{Forgotten Time, or Techniques of Self-Transformation in Contemporary Russian Orthodox Convents}

Translation by anonymous

Daria Dubovka - Peter the Great Museum of Anthropology and Ethnography, Russian Academy of Sciences (St. Petersburg, Russia). ddubovka@gmail.com

From a secular perspective, certain religious techniques of self-transformation, such as the complete subordination of an individual to a spiritual leader, appear to violate fundamental human rights and are hence unacceptable. Conversely, religious traditions offer a different view of the subject and their welfare and the means by which this welfare can be achieved. Nowadays, however, the secular environment in which they operate affects religious groups. As a result, some techniques of self-transformation reflect a mixture of secular and religious worldviews. This article examines techniques of selftransformation in contemporary Russian Orthodox convents. It explores how the notion of spiritual growth is influenced by a paradox in the Russian Orthodox concept of sainthood involving a proportional relationship between the profound perception of one's sinfulness and the increase of one's virtues. The secular understanding of time that prevails in contemporary monasteries highlights this contradiction and calls into question the possibility for spiritual growth. By focusing on the diachronic dimension of self-transformation techniques, this article challenges current understandings of secular and non-secular agency.

Keywords: anthropology of religion, contemporary Russian Orthodox monasteries, techniques of the self, secular and non-secular agency, subjectivity. 
$\mathrm{T}$ the close of the nineteenth century, the emerging field of an-
thropology was not immune to the influence of broader scien-
tific trends; this is evident in the acceptance of an evolutionary paradigm for the field, according to which scientific knowledge must inevitably replace religious faith. However, over the course of the following century, the rising influence of political Islam, the upsurge of neo-Protestant movements, and interest in esoteric practices challenged expectations of the imminent arrival of a secular era. Moreover, anthropologists have come to regard not only religion, but secularism itself as an object of analysis, that is, as a specific ideological system with its own particular dispositions of power, notions of subjectivity, space, and time, and of legitimate methods of argumentation (Asad 2003). We have also reconsidered Western norms concerning the relationship between the state and religious institutions. Nowadays, the exclusion of religion from the public sphere is no longer regarded as inevitable, but rather as only one possible trajectory in the history of states. Secularization, too, is now regarded as a multi-faceted process, which unfolds differently in different nations (Casanova 1994).

For anthropologists of religion, the practices that people utilize to achieve spiritual growth have become a highly contentious topic of analysis. Some of these practices contradict the norms of Western secular subjectivity. Take, for example, the requirement of many religious teachings that a person subordinate his or her own will to the will of another or to the prescriptions of religious tradition. How does one describe the insult and humiliation of a believer who regards their suffering as a purification of the soul? This view of the techniques of self-transformation obviously does not accord with Western understandings of agency, which are based upon the capacity for action motivated by the subject's inner feelings and desires: being inaccessible and invisible to others, these desires must arise from somewhere in the depths of the subject and thus be indisputably their own, unconditioned by tradition or norms, and still less by outright compulsion (Coleman 2005: 128-129). In conjunction with the concept of agency, the idea of "working on the self," which has existed since well before modern times, inevitably came to involve the inner autonomy of the subject and their independence from the authoritarian prescriptions of religious norms. In the European secular tradition, agency was invariably interpreted as the subject's propensity to oppose and even their duty to overthrow oppressive authority (Asad 2003: 71).

In this article, I describe the ways that anthropologists have utilized the theoretical possibilities of the concepts of agency and subjectivity 
to analyze religious practices that disturb exponents of Western secular consciousness. Then, drawing on material collected in contemporary Russian Orthodox convents, I examine what happens to seemingly elegant scholarly models of spiritual transformation if they are forced to contend with the temporal dimension. In this article, time plays a dual role. On the one hand, it is already incorporated into my informants' accounts of spiritual growth, and my task is to examine it in the general context of these "emic" accounts. On the other hand, time is an analytical category, which I propose to consider as an inseparable part of the concept of agency and which is often forgotten in anthropological research.

\section{Theoretical Approaches to the Concept of Agency}

Arguably, some of the most brilliant anthropological studies devoted to the relationships between the state, religious institutions, and the subject have been based on materials from Islamic nations, Egypt in particular (Asad 2003: 205-56; Hirschkind 2006; Mahmood 2005; Mittermaier 2011). This region draws scholars because in its peoples' social imagination and political programs, a complex game is being played out between the privileged "Western paradigm" of conditions for being in the world, on the one hand, and aspirations to create a contemporary government fundamentally incorporating a significantly greater role for religion in the public sphere, on the other. The expansion of the public presence of religion inevitably creates anxiety in Western society, where it is associated with the potential to suppress individual rights and freedoms. However, is not one manifestation of individual freedom a person's voluntary submission to religious tradition?

I want to note in particular an article by Saba Mahmood, in which she contests the description of agency outlined above and proposes a new conception of non-Western religious subjectivity (Mahmood 2001). In her work, Mahmood discusses why many women in Muslim countries have supported the Islamic revival (which includes such things as the wearing of the veil and other clothing restrictions, among other practices that appear oppressive from the European perspective). Prior studies of this question have focused on external factors, such as the pressure of patriarchal society, economic advantages, the low cost and practicality of traditional clothing, upholding social norms, wearing the veil as an expressional of national identity, and so forth. Mahmood paid attention to what the informants themselves were say- 
ing when they explained their return to traditional dress. And by and large they spoke of working on the self, of devotional practices, and of the opportunity to develop habits of virtue by using their external appearance to influence their inner state.

Coming up against the fact that certain groups in non-European cultures view following tradition as a resource for self-transformation, Mahmood proposes regarding agency "not as a synonym for resistance to relations of domination, but as a capacity for action that historically conditioned relations of subordination enable and create" (Mahmood 2001: 203). Thereby, power is conceptualized as a cluster of relations that enable some actions and desires while preventing others, rather than as an exclusively repressive and coercive force. The agency presupposed by Islamic tradition has little in common with the defense of one's interests in opposition to custom, divine will or unfortunate circumstances. Thus, Mahmood disrupts the fundamental connection between agency and readiness to oppose authority that has been longstanding in Western academic thought. The religious system that Mahmood describes encourages certain external actions and disciplinary practices (wearing the veil, for example), which, in turn, are supposed to elicit "correct" feelings and cultivate inner piety. Mahmood calls this process of spiritual work on the self "self-cultivation." She emphasizes the intentionality of such activities, which demonstrates the fallacy of dismissing her informants as passive victims of fundamentalism.

When she presented results of her investigation at conferences and seminars, Mahmood's findings elicited a variety of reactions. Mahmood writes that she had to defend herself against the accusation that she implicitly condones if not "embraces" the oppressed position of women in Islamic societies. However, in her opinion, before one dismisses a particular activity as insulting to human dignity, one must keep in mind one's own European presuppositions and explore the desires and motivations of the people for whom these practices are important (Mahmood 2001: 223-25).

It is no surprise that Mahmood's article provoked heated discussion in American academic circles. From one perspective, her answer to the question of why so many women in Islamic nations had taken to wearing the veil seemed the most "emic" and thus the most sensitive to the culture she studied, inasmuch as Mahmood describes what her informants themselves say rather than invoking external economic and social causality. According to their responses, they adopted the veil as a result of their own free choice and in particular from their de- 
sire for religious self-perfection. But from a different perspective, this kind of explanation undermines rather than reinforces Western notions of agency and the subject, which are among the cornerstones of modern democratic ideology. Accepting Saba Mahmood's conception of agency requires accepting that someone can voluntarily desire to subordinate themself to religious tradition and/or a charismatic leader, and that, in turn, opens the door to legitimizing authoritarian rule.

Besides the above-mentioned ideological anxieties provoked by Mahmood's article, her work also challenges all anthropologists who encounter similar problems in their fieldwork. What are anthropologists to do when, for example, they observe that carrying out some religious practice humiliates informants and that the informants themselves - and not only the outsider - may agree with that interpretation?! But at the same time they insist that the humiliation is useful for their souls, that it offers a path to self-perfection? Should researchers describe the practice critically, and by so doing indicate in one way or another that their informants have developed false consciousness? Or should researchers accept the words of informants and by so doing demonstrate respect for alternative modes of being human, but thereby legitimate the social injustice they observe in the community they study?

Undoubtedly, there is no single answer to this type of question, which fundamentally concerns the evaluation of a culture that is alien to the researcher. Focusing on the gap that Saba Mahmood observes between Western understandings of agency and those offered by other religious systems, I demonstrate that these two different understandings of agency are no longer isolated from one another and that, quite possibly, secular ideas have exerted considerable influence on the contemporary "religious subject." While Mahmood's article discusses Islam, I will consider Orthodox Christianity. The differences in how those two religions approach the subject are less significant to me than their shared divergence from secular ideology.

\section{Self-Transformation in a Russian Orthodox Nunnery}

Despite the fact that to an outsider, a cloister seems to be a rather private social space, contemporary Russian Orthodox monasteries and convents offer the researcher the chance to participate directly in their practices. Restored after the Soviet period, almost all of today's cloisters need assistance with labor, and therefore eagerly accept temporary laborers. Among the laborers are people who for a variety of rea- 
sons want to spend days or months of their lives in a cloister, often without the intention of remaining there for good. In some cloisters, especially small ones, temporary laborers quickly become a part of the monastic sisterhood or brotherhood, which means that these groups meet not only during church services but that they work together on tasks of obedience (poslushaniia, that is, daily labor obligations) and share meals. As a result, participating in monastic life as a temporary laborer allows the researcher to observe everyday life in a cloister closely. ${ }^{1}$ The everyday life of the residents of one such convent, located in a small town in central Russia, constitutes the ethnographic foundation for this article.

In the fall of 2012, I spent two weeks in this small convent, whose population consists of eleven people: five nuns (monakhiny), four novices (inokiny) and two lay sisters (poslushnitsy). I already had extensive experience of life in various cloisters, so I was familiar with the basic rules and logic of everyday life in a convent. My first week was spent in a cloister deprived of leadership: both the abbess, the head of the nunnery, and the orderly, her assistant, were in the hospital. The most sensible lay sister had been appointed as elder. Either because of her character or because of her limited time in the position and lack of authority either to punish or to instruct spiritually, her leadership was rather democratic, and she tried to heed the wishes of the other nuns. However strange it seemed to me, some were not pleased with this gentle style of leadership, perhaps because it left no room for disciplinary practices, a powerful resource for self-transformation. The abbess's habitual style of leadership differed quite strikingly from that of her replacement. I first encountered it in fact before the abbess returned. Below, I offer two excerpts from my field diary, slightly altered to reduce the emotional tenor and improve the consistency of the text. These excerpts are not written in an objective scholarly style. However, their undertone of surprise and a certain irony convey clearly the feelings of a person who professes secular values and finds herself in a religious milieu. As I have already emphasized above, in the case of fieldwork, the conceptualization of agency ceases to be an exclusively

1. In accordance with research ethics, I do not conceal my scholarly purposes when observing cloister life, which elicits a variety of responses: from the desire to chat with me and explain some aspects of monastic life, to openly doubting the need for my work and affirmations of the usefulness of secular knowledge. The nuns predominantly described in this article asked that their convent not be identified, saying that otherwise publication would attract too many pilgrims (apparently failing to distinguish between journalistic and scholarly publication). 
theoretical question, insofar as the conduct of the researcher and their interactions with informants depends on it.

It was the end of September - time to dig potatoes. A busload of pilgrims arrived at the nunnery to help. They had to be fed. The abbess telephoned from the hospital and gave her instructions - fry fish patties - and dictated the recipe. When it came time to prepare the meal, the nuns began feverishly to discuss the cooking techniques indicated by the recipe. The nuns who participated in the discussion were all middle aged or elderly, and they had various degrees of culinary experience, but the recipe immediately confused them all, because it called for too little milk and too much bread for the amount of ground fish. I was sure that they would set aside the recipe and begin cooking on the basis of their own experience and common sense, but evidently I did not understand the power of the recipe. The nuns read it again and again. One of them, Efrosina (I have changed all names), exclaimed from time to time: "The blessing ${ }^{2}-$ this is right, this must be done, of course, it's been blessed that way," but would then immediately add that she would use less bread. Another moment passed, and Efrosina became distressed: "But who am 'I,' 'I' is - yuck, you shouldn't even say the word 'I.'” After that, her good sense once again gained ascendancy and she added: "Yes, of course, there's the recipe, but you have to do a little thinking for yourself, too." However, there was something subtly dangerous about thinking for oneself. As a result, everyone decided to proceed exactly as the recipe indicated, thanks to which an additional technical operation had to be added to the process of preparation: the fish had to be put through the grinder a second time, which took three hours of working time, but this bothered no one. When they finally managed, with great difficulty, to prepare the ground fish, the nuns discovered a concluding point in the recipe: salt and pepper according to taste. That point elicited another feverish discussion. Whose taste should be considered the model? Naturally, the abbess should be the deciding taster, but in her absence, who would take it upon herself to offer an expert opinion on the patties' degree of saltiness? Late in the evening the abbess telephoned to find out how things were going. These adult, even elderly women described in great detail and with high spirits what was taking place in the kitchen, who was doing what, whether the griddle was clean and what color the

2. In monastic life, blessing is very closely connected to obedience - essentially, a blessing is either the permission or an order to do something, and ordinarily the abbess's blessing is needed for every undertaking (Rousselet 2011: 298-316; Dubovka 2015, 6381; Zabaev 2007: 5-26). 
patties turned while they were frying. It's possible that I lack culinary refinement. However, never before have I encountered such a literalist approach to a recipe. For me, food preparation is a matter of fortune and circumstance, whereas in this nunnery other forces, which I still do not understand, were concealed in the kitchen.

For this viewer, an outsider, the absurdity was that a routine, profane practice, cooking, had become a part of the practice of religious selftransformation. After the abbess returned it became even more graphically clear to me that cooking could facilitate moral growth.

At dinner, one of the lay sisters, I'll call her Tamara, was supposed to prepare stewed cabbage. Mother, as the nuns call the abbess, tried the cabbage, and was very dissatisfied with its taste (and it must be said that the dish was not a success). Tamara began to explicate in detail the steps she had taken while cooking, trying to understand where she had gone wrong. Finally, the root of the evil was discovered -it was a pepper that the lay sister had dared to add on her own account. I thought that this odd investigation of food would end at that point. But no, Mother spent at least another half hour blaming the lay sister's vanity for the failure of the cabbage. Last time Tamara was praised, she said, so this time she wanted to outdo herself and came up with the idea of improving the recipe by adding pepper. Tamara timidly observed that of course a person hopes to do better. This further enraged the abbess: "So a person hopes to do better! But what's needed is not to do better, but to do according to the blessing! And you, you want to have your own will in everything!" Tamara almost burst into tears. Afterwards, the abbess spent some time discussing with the orderly whether Tamara could be trusted with preparing food for the pilgrims who were arriving. The orderly asked the lay sister: "Can you handle it?" Tamara: "I'll try." The abbess: "What, again 'I'll try!' As God wills - and there you go again, with your will.” Tamara was now in tears: "Mother, I always say to myself - as God wills."

After that conversation the lay sister, walking with me back to our quarters, no doubt understood from the look on my face that an explanation was needed. Tamara said that Mother was actually very kind. I expressed reservations. Tamara went on. The abbess set it all out very well for her, she said. She herself failed to understand why we don't notice our hidden sinful passions, but the abbess noticed the sin and pointed it out. And Tamara found the public rebuke very useful, because that is exactly the way God humbles the proud - they have to be criticized in front of others. It is only while you are a novice that they coddle you; 
as soon as you grow spiritually stronger, they start treating you much more strictly. But that only means that you've strayed from the proper path and God is correcting you.

Two points can be taken from Tamara's words. Firstly, hidden sin dwells within a person - hidden above all from the very person who carries it, while the public exposure of that sin cultivates the virtue of humility, which fosters the person's salvation. I will examine this understanding in detail.

Hidden sinful passion. According to Russian Orthodox anthropology, humans are sinful by nature from the moment of their birth as a result of the Fall of Adam and Eve. The sacrament of baptism cleanses believers of original sin, but much more work is required for them to overcome their own impure inclinations. Except for a few religious virtuosos, most people are so sinful that they fail to realize their sinfulness or are only able to realize it in a general kind of way, without seeing any of the concrete manifestations of their deplorable state.

The unmaskers of passion. Abbots, clerics, elders and all those who are called to pastoral leadership fulfill this role. An abbess must search for sin in the charges under her guidance. If she does not, it means she is not concerned with their spiritual life, and the nuns themselves will be dissatisfied with her.

The manifestation of passion. Work on the self begins with understanding one's current state. Sinful passions reveal themselves through a person's actions, but this is not the only method that Christian tradition has developed for discovering them. For example, tradition attributes to elders, both male and female, the ability to comprehend a person's spiritual state from the very first glance. From early Christian sources, Michel Foucault has examined monastic techniques of selftransformation, such as revealing to one's confessor one's most petty impulses and desires (Foucault 2008: 118-122). In this flow of confession (or self-descriptions), it is the duty of the confessor to distinguish the good thoughts from the bad. In today's monasteries, pastoral leaders base their interpretations on more objective, palpable things such as poorly prepared food, incorrect placement of icons on the lectern, or mistakes made while reading a prayer during a religious service. In this manner, any failure to observe the rules, written, unwritten, or merely implied by the leadership is treated as a manifestation of the sin of pride. The convenience of this form of spiritual leadership is that any sin a nun commits can almost always be visualized 
and made concrete - for example, as a pepper added to a dish, as in the above example.

Obedience. In the context of quotidian labor operations, obedience becomes an instrument for facilitating the search for sin. Obedience becomes a rule that makes any deviation from it evident, and all the more so because in many cases the rule itself makes that deviation inevitable. For example, in the incident of the prepared dish described above: from a culinary perspective, it was necessary to depart from the given recipe, but according to the "spiritual economy" it was necessary to follow it precisely. It is no wonder that the nun Efrosina was so tormented by the choice between relying on her own common sense and submitting to the culinarily dubious wishes of the abbess. As soon as Efrosina began speaking of how reasonable it was to alter the recipe, she interrupted herself, blaming her own "ego." Thus, the practical solution was linked to pride. The irony is that any choice a person makes can be interpreted as a fault. Everything depends on the interpretation that the Mother prefers. Here, for example, is another excerpt from my field journal:

In her absence, the abbess ordered the purchase of sawdust to line their storeroom floor. When she got back, the abbess denounced the lay sister Tamara, who had served as elder, for being unable to find dry sawdust. Tamara responded that the sawdust brought the day before was practically dry. The abbess then replied as follows: "In that case, why didn't you realize you needed to order another car full? We need a lot of sawdust. You've got to think ahead a bit."

Clearly, even conscientiously following the rules cannot preserve a nun from reproach. In the everyday life of her flock, an abbess can always find things to criticize in which a nun herself will have failed to consider the spiritual significance. Then, the nun responds with surprise and frequently, non-acceptance, inasmuch as what she has been told does not correspond to her picture of what has happened or to her inner sense of the matter. The most difficult part of my study was observing nuns' confusion and initial refusal to accept the abbess's interpretation, sometimes accompanied by tears. But if one sets aside a secular understanding of agency, then it becomes clear that in the monastic system of values, humiliation signifies spiritual growth.

Humility. It is a good sign when a spiritual charge finds it unpleasant to be chastised. It means that she is being worked on spiritually. In this emotional plan, fear and humiliation constitute an integral 
part of monastic agency. And, by this logic, I should have rejoiced for Sister Tamara when the abbess unmasked her, insofar as this brought her closer to salvation.

At this point, it might be possible to summarize things, concluding that models of the "Western subject" and "Western norms of agency" are irrelevant to non-secular traditions. For example, the contemporary monastic subject manifests agency in consciously accepting the interpretations of their religious state from their spiritual mentor, who presumably has trustworthy knowledge of the desires and impulses of the person being instructed, even as the person themself cannot perceive the real reasons for their actions. In the Egyptian field, Saba Mahmood comes to a similar conclusion about an alternative conception of agency. However, it seems to me that this conclusion is somewhat premature, and here is why.

In the contemporary world, all communities are to some extent familiar with secular norms and values. According to Charles Taylor, competing ways of representing the self and the world are the distinguishing feature of a secular age: "naïve" faith that particular dogmas and practices are the best/true/the most appropriate, coexists with an awareness of other approaches to the universe, be they atheistic or constructed on other religious postulates (Taylor 2007: 12-14). Because of this, the "naïve" view is interwoven with a "relativistic" one, unavoidably raising doubts. Of course, the relationship between the "naïve" and "relativistic" views will vary from culture to culture. And it is possible that while the European discourse concerning the subject and their rights is an integral part of the media in the Islamic society that Mahmood describes, it does not dominate, especially among certain groups. Nevertheless, the complete and absolute domination of the "naïve" view is hardly possible today, even in such societies.

The same is true in this case. All my informants share a post-Soviet past, in which the understanding of the subject and agency differ from the Western understanding, but not nearly so fundamentally as in traditional societies. ${ }^{3}$ Therefore, in contemporary nunneries, the "relativistic" and "naïve" outlooks will be even more entangled and confused. Indeed, the "naïve" views of the contemporary inhabitants of a given nunnery are the religious views that they often learned as adults, when

3. What I term traditional societies/cultures are those that classical anthropology examined - small, local groups, primarily pre-literate and having had little contact with Europeans. 
they turned to the faith. ${ }^{4}$ And that means that those views are hardly likely to become as unshakeable at any point as the ideas of people who were raised in a religious culture and lack alternative accounts of themselves, others and the world.

\section{The Temporal Dimension of Agency}

Orthodox Christians hold a variety of perspectives on the nature of the subject. According to the research of Jarrett Zigon, conducted in Moscow during the first decade of the 21st century and devoted to conceptions of morality and ethics, the believers among his informants expressed the need to treat other people respectfully, since every person is a spark of God/the image of God (Zigon 2009: 1-26). However, this attitude toward one's neighbor is not widespread in contemporary monasteries. The tradition emphasizing the sinful nature of every person has emerged as an alternative, but that way of perceiving the self is unfamiliar and problematic for the nuns, I maintain (Knorre 2011: 317-40). The nun Efrosina expressed surprise when she learned about the Russian Orthodox tradition proposing that even (or first and foremost) a saint will perceive themself to be a sinner until the end of their days: "How hard, I thought, can I really be so bad - and it turns out that every saint has endured such spiritual struggle until the end of their life."

This inner contradiction between a person's customary self-image and the one cultivated in a monastic cloister can become the core of an entire spiritual life for a long time. According to Niklaus Largier, an emotional drama of this sort played a significant role in the life of medieval Catholic monasticism (Largier 2008: 73-91). Naturally, it was based on different aesthetics and practices. However the emotional dynamic followed a comparable scenario. In the nunnery I am describing, the development of spiritual life can be presented as follows: a person who is sinful but does not know this is shown (in this case, by the abbesses' words) their genuine, sinful nature. At first, the "sinner" rejects this unappealing image and refuses to recognize herself in it; after that comes catharsis, and the person regards herself and her motivations in a different light. Paradoxically, the discovery of one's sinful

4. The overwhelming majority of the nuns in the nunneries I studied turned to the faith in the early 1990s. Usually, only the abbess had experience of religious life - had entered a nunnery - in Soviet times. As a matter of fact, thereafter the church leadership often appointed an abbess to a newly opened cloister on this basis, that is, her having had experience of monastic life. 
nature turns out to be the guarantee of salvation, inasmuch as from that moment, the person sees the truth about themself and can begin ascending the path to virtue. In Largier's portrayal, the spiritual life of a Catholic monk in the Middle Ages was built mainly on the work of the imagination. During prayers, the monk began with the most detailed possible conception of hell, torments and temptations (complete with smells and sensations). And when he succeeded in bringing these horrible scenes to life, out of terror at his own future portion he pictured God's mercy, and the hope of divine transformation of his sinful soul brought about the desired catharsis.

These two styles of spiritual life are related in that they are both cyclical. Time and again, the same mechanisms provide the hope of salvation or an authentic vision of oneself as the culmination of similar religious experience. However, in the Russian religious tradition, many texts portray a different trajectory of spiritual life. These texts describe a gradual growth in virtue and thus, the path to God as an ascending line and not a "sinusoid" of emotional ups and downs.

"The Ladder of Divine Ascent" by John Climacus offers one of the most well-known images of ascension (Sinaiskii 1998). Composed in the seventh century, this tract envisions spiritual ascension as thirty rungs of virtue. Beginning at the bottom rung of renunciation of earthly vanity, the person who craves the Kingdom of Heaven ascends to penitence, to struggle with the passions, to ascetic feats, and at last reaches the summit, which unites the three main virtues: faith, hope and love. Nowadays, you do not have to read the book to be familiar with the image of the ladder, because the portrayal of the ladder leading to heaven, with monks ascending it, is very popular in Byzantine and Russian iconography.

There are other theologians whose works discussing the progressive cultivation of virtue are closer to contemporary thinking. The writings of two 19th-century saints, Feofan Zatvornik and Ignatii Brianchaninov, have been widely published in the past decade. In Russian Orthodox academic circles, their writings are regarded as the foundation for understanding spiritual life, because it was precisely they who made the early Christian patristic tradition available in a language that their contemporaries could understand and that is therefore closer to us, too. The Path to Salvation by Feofan Zatvornik contains the temporal aspect of spiritual life even in its chapter titles: "the sinner's awakening from sinful sleep," "ascending to the decision to abandon sin," "how Christian life is carried out, matures and becomes stronger in us," "the elements of ascension to liv- 
ing communion with God" (Zatvornik 2001). This is only an abbreviated list of chapter titles. Many of the subsections, in turn, have a step-like structure. Thus, for example, human nature is depicted as consisting of three parts - the Spirit, the Soul and the Body, which exist in hierarchical order. In the lowest part - the body - the sins of sexual immorality, sloth and gluttony develop; envy, despondency, bitterness, wrath, vanity and lust find a refuge in the soul; the spirit can suffer from the hardening of feelings, self-absorption, audaciousness, self-satisfaction, indifference to the spiritual, and selfjustification (Zatvornik 2003: 19, 65-190). Consequently, the struggle with these sins also proceeds in stages and in hierarchical order from lowest to highest.

The book Ascetic Exercises by Saint Ignatii Brianchaninov is a collection of articles, written at various times and collected and edited by the author at the end of his life. As a result, its structure is less coherent than The Path to Salvation (Brianchaninov 2011). Nevertheless, it has the very same sections on penitence, the eight primary evil passions and means of struggling with them, and the basic virtues that will take their place. The book pays a great deal of attention to prayer in general and the Jesus Prayer in particular. ${ }^{5}$ The latter is presented as the pinnacle of monastic practice: the fulfillment of that prayer, when it achieves perfection, becomes the basis for communion with God.

The above-mentioned works of Ignatii Brianchaninov and Feofan Zatvornik are usually familiar in one way or another to the inhabitants of cloisters and to many of the people who come to labor there. Members of the clergy have even expressed their displeasure with the popularity of these books or of similarly structured contemporary compilations of writings by the holy fathers. Several of the temporary laborers in the convent I studied told me that their priests recommended to parishioners that they not read the writings of these saints, saying that such books contain recommendations for monks, that is, for people already experienced in spiritual life. When beginners try immediately to carry out that which is most difficult - the Jesus Prayer - they will fail and become disillusioned or fall into the sin of pride.

5. The Jesus Prayer is the short phrase: "Lord Jesus Christ, Son of God, have mercy upon me, a sinner." It is particularly closely associated with Hesychasm, a mystical Christian current that links the possibility of the deification of the person with the constant reiteration of that prayer. 
Thus, the clear hierarchy of sins, the prescribed order of replacing them with virtues and the evident goal of the spiritual path the unceasing Jesus Prayer - together provide the various steps of the spiritual path. And some of those who seek monastic life arrive at the cloister familiar with some version of the practice of gradual self-transformation. To them, the cloister appears to be what can be called in scholarly language a "disciplinary institution." Indeed, for those faithful who wish to proceed as far as possible in their spiritual development, entering a cloister must seem the most logical life choice - a chance to "professionalize" their interest. However, after spending some time in a cloister, nuns whose aim is working on the self come up against this: the understanding of human nature to be found in contemporary monasteries is incompatible with techniques of self-transformation based on a metaphor of progress. How can we speak of self-transformation if there are no criteria for understanding one's own spiritual growth and the person working on the self cannot become conscious of their own success? Indeed, only after a person dies does it become possible to identify their saintliness or sinfulness with relative certainty, and, in the final analysis, God alone can judge a person's soul.

To explore this question in more detail, I return to the concept of the disciplinary institution and the techniques of self-transformation with which it is closely linked. As presented by Michel Foucault, disciplinary institutions can be characterized according to the following parameters. Students/patients/soldiers and the like can be classified according to a scale of norms and deviations. However, no such scale exists in a monastery. A person always knows ahead of time that they are sinful, because the norm is saintliness. But according to the canons of the Russian Orthodox Church (ROC), a person can be declared a saint, canonized, only after their death. Therefore, the sole interest of the nunnery is to identify the nuns' deviations from the norm - that is, to reveal their sinfulness. Furthermore, there exists in Orthodox tradition the belief that if a person follows the correct path, then the closer they approach God, the more clearly they will see even the most minor sin in themselves. Hagiographies that portray saints who weep on their deathbed and confess themselves to be great sinners typically confirm that idea (and also serve as a kind of guide for behavior). In this sense, a cloister logically assumes the role of a particular kind of surveillance system, aimed at revealing everything that is false in its inhabitants if the inhabitants do not do that for themselves. And should a monk 
or nun be inclined to investigate their own behavior and thoughts, then the harder they work on themselves, the more they will see their own sinfulness. This is also development - but it is only inner growth. Ideally, the cloister (or the person themself) must regard a nun's every action and step as sinful. In addition to everything else, this can be seen in the complete lack of praise and gratitude in contemporary convents.

In the traditional disciplinary institutions that Foucault identifies, the trainee must be taught new skills. It is hard to say the same about contemporary cloisters: nothing preserves a person from being regarded as a sinner, and, what is more, the person should regard themself as such. The only new skill that nuns actually do acquire in a cloister is the ability to interpret their everyday behavior as sinful. The method is quite simple: ordinarily, only a single evil passion - pride/ vanity - manifests itself in obedience, that is, routine household operations. A person performs something incorrectly - this demonstrates their pride. To the extent that spiritual life has become a matter for interpretation, the struggle with evil passions always comes too late, because the nun becomes aware of sin (or it is pointed out to her) only after it has been committed. However, patristic literature presents the struggle with the passions as attentiveness to thoughts and the ability to discern the consequences before engaging in action. In contemporary cloisters, by contrast, (self-)punishment for actions already performed has replaced that struggle. At first the person's sinful nature was hidden; then the abbess pointed it out; then followed repentance, prayer, penance. But the nuns are doomed to repeat this pattern endlessly - endlessly, because sin cannot be eradicated and is connected to the repeated acts of labor.

None of this corresponds well to the work of a disciplinary institution or, in theory, to didactic logic. In a cloister, there is no scale by which to measure the acquisition of a new skill, to examine it, to carry out exercises to solidify it and the like. That is, what is taking place is not work on the soul, which presupposes change and the possibility of ascertaining it, but rather the "recursion" of the discovery of sin in parallel contexts.

I think that by no means all inhabitants of cloisters experience this contradiction between their vision of spiritual growth and what really happens in practice. Some, for example, find significance in their very presence in a sacred space. But those who entered the nunnery with the idea of work on the soul as a complex of systematic exercises in which progress might be observed sooner or later reach a dead end. 
According to patristic doctrine, those who aspire to be monks or nuns must first examine their own soul to discover the sins/passions from which they must be delivered. However, the contemporary nunneries of the ROC with which I am familiar practically focus on only a single sin - vanity/pride, while evidence of "work on the self" becomes the presence of sins (that is, catching sight of them), and not their eradication, however paradoxical that may seem.

When they first become acquainted with this system, the women who come to the convent to work on themselves deal with it by interpreting their everyday life as the manifestation of evil passions and by working out their emotional reaction to these discoveries. However, once they have learned to structure their everyday experience according to the new categories, the system ceases to develop. However much this may contradict the works by the saints cited above, in Orthodox tradition it is practically impossible to declare with confidence: I have overcome such and such a sin or developed such and such a virtue. In patristic literature this is called self-delusion (prelest') - the highest form of pride and self-deception. It is worth remembering the above-mentioned words of the nun Efrosina, who became distressed when she realized that the spiritual struggle was to last a lifetime, as was the perception of oneself as a sinner.

The lack of progress in the techniques of self-transformation prevalent in contemporary convents periodically prompts inhabitants to abandon the cloister. This happened time and again, for example, in the Resurrection Goritsy Convent in Vologda Oblast, which I visited over the course of several years. During my first visit, I saw only the cyclical schema of spiritual life: inhabitants made mistakes in the course of their labors of obedience and, as a result, became aware of their own sinful nature. This behavior perplexed me, but as a researcher I was forced to recognize that the nuns or novices expressed their agency - in complete conformity with Saba Mahmood's concept of agency - precisely in subordinating their own will to that of the abbess. However, people left Goritsy one after another, having decided at a particular moment that their development in that particular convent had ceased and was unlikely to resume in the future. Moreover, from my Russian Orthodox acquaintances who visit various monasteries, I increasingly heard stories about schisms within cloisters, about the great "turnover" among inhabitants and about the return of some sisters to the secular world. Those of the latter with whom I managed to speak personally believed that they had ex- 
hausted the possibilities for spiritual growth in their convent. In a new cloister or in their urban apartment they hoped they would be able to devote more attention to intense prayer, which would purify their soul and help to make possible their unmediated communication with God. This interest in mysticism, the "hesychastic" tendency in Russian Orthodoxy, merits its own study. Here I only want to emphasize that many who join convents in anticipation of spiritual growth find the constant repetition of one and the same practice to be manifestly inadequate.

\section{Conclusion}

The reason I changed my initial views on the nature of monastic agency (that is, subordination to the abbesses' will) is because changes occurred in the field itself: convents became divided; their inhabitants returned to the world. This diachronic aspect of the research forced me to recognize that the academic definition of agency presupposes an unchanging subject, who either opposes authority/tradition (the reigning Western paradigm) or (according to Mahmood) subordinates themself to it.

But does this unchanging subject exist? Recalling the words of Charles Taylor concerning the blending of the "naïve" and "relativistic" perspectives in the "secular age," it is possible to presume with confidence that in post-Soviet space, at least, the majority of informants will be familiar with more than one way of regarding the world and their place in it. For example, those believers who, entering a cloister, try to master Christian norms of authority relations and conceptions of the subject and their desires and motivations, norms that are unfamiliar to them because of their Soviet past, might nevertheless retain a secular understanding of linear time. Although the secular understanding of time derived from Christian eschatology and has much in common with the image of linear ascension described by John Climacus, it was in modern times that it became virtually universal. All institutions of socialization - the school, the university, the army - are founded on the idea that development advances progressively. Consequently, the contemporary person who wishes to become proficient in something will naturally evaluate their activity by comparing the time and energy they devote to it with the degree of their success in reaching their goal.

Such faith in the progressive development of one's abilities has had a disastrous impact on contemporary monasteries and convents. In 
the first place, it ignores the paradox in Eastern Orthodoxy: that virtue increases even as awareness of one's own sinfulness deepens. Secondly, the recursive model of spiritual life prevalent in the convents I studied does not correspond to the goal of progressive development. Here, I will risk making the assumption that most people who pass through secular institutions of socialization have a concept of spiritual development that incorporates a secular notion of time. The pressure of secular time, by the way, manifests itself even more forcefully in cloisters than in the lives of laypeople, because for a portion of the people who enter monasteries, becoming shriven was a rational choice about how best to progress towards the Kingdom of Heaven during the short span of earthly life, whereas the lives of laypeople, even in the conditions of a period of "religious revival," involve more than spiritual practice.

In conjunction with the significance of the "temporal factor," the situation surrounding the current rebirth of Islam in Egypt makes me wonder whether the heroines of Saba Mahmood's article have continued their religious practice over the long term. As Mahmood noted, her informants were counting on the culminating effect of their disciplinary practices rather than on their mechanical repetition (Mahmood 2001: 216). In the case of contemporary Egypt, that means, for example, that wearing the veil for a long time must at some point lead to inner virtue. How far were Mahmood's informants from the desire not only to follow tradition but also to evaluate the success of their path, to measure their own growth?

Nowadays, the academic concept of agency is, in essence, built upon the ascribing of a variety of types of actions to one or the other of two opposing positions: activity or passivity. Saba Mahmood changed the usual vector of description by asserting that submission can be characterized as "activity." It seems to me that one and the same behavior (for example, obedience), viewed according to the scale of secular time, may be initially regarded by informants as an active and conscious choice, as work on the self. To the researcher, this will be viewed as a manifestation of agency. Subsequently, however, when the very same activity becomes routine, it will become unnecessary to informants and they will try to avoid it - and the researcher will also change the sign in their description of agency. Presupposing constant change, the obsolescence of previous practices, and the introduction of new ones, linear time influences the religious practices of many of the faithful. Academic studies of the faithful should bear that in mind. 


\section{References}

Asad, Talal. (2003). Formations of the Secular: Christianity, Islam, Modernity. Stanford, CA: Stanford University Press.

Brianchaninov, Ignatii. (2011). Zhizneopisanie. Asketicheskie opyty. Kniga pervaia [Hagiography: Ascetic Experience; Book One]. Moscow: Blagovest.

Casanova, Jose. (1994). Public Religions in the Modern World. Chicago: University of Chicago Press.

Coleman, Janet. (2005). "Pre-Modern Property and Self-Ownership before and after Locke: Or, When Did Common Decency Become a Private Rather Than a Public Virtue?" European Journal of Political Theory 4: 125-45.

Dubovka, Daria. (2015). "Poslushanie kak fizicheskii trud i kak dobrodetel': Semioticheskoe nasyshchenie proizvodstva v sovremennykh monastyrei RPTs." [“Obedience as Physical Labor and as Virtue: The Semiotic Content of Production in Contemporary Russian Orthodox Convents"] In Zh. Kormina, A. A. Panchenko, and S. A. Shtyrkova (Ed.), Izobretenie religii: Desekuliarizatsiia $v$ postsovetskom kontekste [The Invention of Religion: De-Secularization in the Post-Soviet Context] (63-81). St. Petersburg: Izd-vo Evropeiskogo Universiteta v Sankt-Peterburge.

Foucault, Michel. (1975). Discipline and Punish: The Birth of the Prison. New York: Random House.

---. (2008). "Tekhnologii sebia" [“Techniques of the Self”]. Logos 2: 96-122.

Hirschkind, Charles. (2006). The Ethical Soundscape: Cassette Sermons and Islamic Counterpublics. New York: Columbia University Press.

Knorre, Boris. (2011). "Kategorii 'viny' i 'smirenie'v sisteme tsennostei tserkovno-prikhodskoi subkul'tury." ["The Categories "Guilt" and "Obedience" in the Value System of a Parish Church Subculture”]. In A. Agadzhanian, K. Rousselet (Ed.), Prikhod i obshchina $v$ sovremennom pravoslavii: Kornevaia sistema rossiiskoi religioznosti [Parish and Community in Contemporary Russian Orthodoxy: The Roots of Russian Religiosity] (317-40). Moscow: Izd-vo "Ves' Mir"

Largier, Niklaus. (2008). "Praying by Numbers: An Essay on Medieval Aesthetics," Representations 104(1): 73-91

Mahmood, Saba. (2001). "Feminist Theory, Embodiment, and the Docile Agent: Some Reflections on the Egyptian Islamic." Cultural Anthropology 16(2): 202-36.

---. (2005). Politics of Piety: The Islamic Revival and the Feminist Subject. Princeton: Princeton University Press.

Mittermaier, Amira. (2011). Dreams That Matter: Egyptian Landscapes of the Imagination. Berkeley: University of California Press.

Ioan, igumen gory Sinaiskoi. (1998). Lestvitsa [The Ladder]. Kiev: Kievo-Pecherskaia Lavra.

Rousselet, Kathy. (2011). "Ob otnosheniiakh mezhdu sviashchennikami i mirianami: Poslushanie i blagoslovenie" ["On the Relations Between Priests and Laity: Blessing and Obedience"]. In A. Agadjanian, K. Rousselet (Ed.), Prikhod i obshchina $v$ sovremennom pravoslavii: Kornevaia sistema rossiiskoi religioznosti [Parish and Community in Contemporary Russian Orthodoxy: The Roots of Russian Religiosity] (298-316). Moscow: Izdatel'stvo "Ves' Mir."

Taylor, Charles. (2007). A Secular Age. Cambridge: The Belknap Press of Harvard University Press.

Zabaev, Ivan. (2007). "Osnovnye kategorii khoziaistvennoi etiki sovremennogo russkogo pravoslaviia" ["The Basic Categories of Economic Ethics in Contemporary Russian Orthodoxy"]. Sotsial'naia real'nost' [Social Reality] 9: 5-26. 


\section{ARTICLES}

Zatvornik, Feofan. (2001). Put' ko spaseniiu: Kratkii ocherk khristianskoi asketiki [The Way to Salvation: A Short Outline of Christian Ascetics]. Moscow: Blagovest.

---. (2003). Strasti i bor'ba s nimi: Vyderzhki iz tvorenii i pisem [Sins and the Struggle against Them: Excerpts from Works and Letters]. Moscow: Danilovskii Blagovestnik.

Zigon, Jarrett. (2009). "Developing the Moral Person: The Concepts of Human, Godmanhood, and Feelings in Some Russian Articulations of Morality." Anthropology of Consciousness 20(1): 1-26. 